\title{
Hereditary Hypophosphatemic Rickets with Hypercalciuria
}

National Cancer Institute

\section{Source}

National Cancer Institute. Hereditary Hypophosphatemic Rickets with Hypercalciuria. NCI Thesaurus. Code C131450.

An autosomal recessive form of hypophosphatemic rickets caused by inactivating mutation(s) in the SLC34A3 gene, encoding sodium-dependent phosphate transport protein $2 \mathrm{C}$, a protein involved in maintenance of inorganic phosphate concentration in the kidney. The condition is characterized by elevated 1,25-dihydroxyvitamin D (calcitriol) concentrations, resulting in increased intestinal calcium absorption and hypercalciuria. This form of hypophosphatemic rickets is also disting uished by the lack of elevated fibroblast growth factor 23 (FGF23) concentrations. 